\title{
MENGENAL PENULIS KITAB YAKOBUS DAN PENGAJARANNYA
}

\author{
Demsy Jura \\ Universitas Kristen Indonesia \\ Program Studi Magister Pendidikan Agama Kristen \\ demsy.jura@uki.ac.id
}

\begin{abstract}
Salah satu kitab yang terdapat dalam Alkitab, khususnya dalam Perjanjian Baru adalah Kitab Yakobus, di mana kitab ini sempat menjadi pokok pembicaraan hangat di kalangan teolog
\end{abstract} Kristen berkaitan dengan keabsahannya. Informasi mengenai hal ini akan terungkap ketika seseorang melakukan kajian khusus mengenai Kitab Yakobus, dan haruslah diakui bahwa dari beberapa kitab yang ada dalam Alkitab, nyata sekali Kitab Yakobus menjadi salah satu kitab yang menjadi pokok perbincangan yang cukup serius berkaitan dengan keabsahan kitab ini. Apakah kitab ini bisa atau tidak masuk dalam bagian dari Alkitab yang telah diterima dalam kanonisasi ${ }^{1}$ masa gereja mula-mula.

\footnotetext{
1 Kanonisasi merupakan suatu proses di mana kitab-kitab yang dianggap memenuhi kriteria diterima. Secara historis, istilah kanon itu sendiri menunjuk bagaimana suatu kitab dianggap memiliki norma dan otoritas bagi iman dan kehidupan gereja. Proses pengkanonan ini dilakukan oleh puluhan ahli kitab suci dan juga ahli bahasa yang dengan teliti dan secara serius memilah-milah banyak tulisan yang dianggap suci untuk menemukan kitab-kitab yang benar-benar diwahyukan Allah untuk kemudian dijadikan satu dengan pertimbangan bahwa kitab tersebut ditulis atau disahkan oleh para nabi atau rasul. Kitab tersebut diakui otoritasnya di kalangan gereja mulamula, dan kitab tersebut mengajarkan hal yang
}

Kenyataan bahwa Kitab Yakobus masih tetap diperdebatkan keberadaannya oleh beberapa pihak merupakan hal yang tidak terabaikan dalam sejarah Alkitab. Pada tahun 70, ada sejumlah kitab dalam Alkitab yang diperdebatkan sehingga tidak tampak dalam beberapa versi terjemahan Alkitab. Beberapa kitab yang dimaksud di antaranya adalah: Kitab Yakobus, Kitab Ibrani, Kitab 1 Petrus dan Kitab 2 Petrus. Kitab-kitab tersebut tidak tercantum dalam beberapa terjemahan Alkitab. Kitab-kitab tersebut di atas dianggap tidak memenuhi persyaratan kanonisasi. Akibatnya, kitabkitab yang dimaksud tidak tercantum dalam beberapa versi Alkitab, di antaranya pada direktori Fragmen Muratorian ${ }^{2}$ dan juga pada versi Alkitab lainnya, yaitu

selaras dengan kitab-kitab lainnya yang jelas termasuk dalam kanon.

2 Fragmen Muratorian atau The Muratorian fragment, yang juga dikenal sebagai The Muration Canon atau Canon Muratori merupakan naskah bahasa Latin dari abad ke-7 yang terjilid dalam sebuah codex bertanggal abad ke-7 atau ke-8 yang diduga berasal dari perpustakaan biara Columban di Bobbio. Naskah itu merupakan terjemahan dari manuskrip bahasa Yunani yang ditulis sekitar tahun $170 \mathrm{M}$ itu sudah dalam kondisi rusak sehingga menyulitkan para ahli untuk menyelidikinya lebih lanjut. Dalam The Muration Canon, semua kitab dalam Perjanjian Baru tercatat, kecuali Kitab Ibrani, Kitab Yakobus, Kitab 1 Petrus dan 2 Petrus. 
terjemahan Alkitab The Old Latin. ${ }^{3}$

Bahkan dengan nyata bahwa Kitab

Yakobus tidak termasuk dalam kelompok

kitab tersebut, padahal terjemahan-

terjemahan itu merupakan terjemahan yang

diakui sebagai kitab suci yang memiliki otoritas ilahi di dalamnya.

Tentunya keadaan tersebut membuat para ahli memikirkan Kitab Yakobus sebagai salah satu kitab yang menjadi bahan pembicaraan serius karena aspek yang ditimbulkan, yang karenanya sangat menentukan keberadaan gereja dalam dunia ini. Tidak bisa dilupakan bahwa semua kitab dalam Alkitab telah teruji sehingga dapat diterima dan dipergunakan sebagai sumber utama pengajaran iman Kristen. Itulah sebabnya maka kitab-kitab yang dimaksud tersebut di atas menjadi pegangan gereja dalam mengajarkan iman Kristen. Jadi tidaklah berlebihan jika dikatakan bahwa kitabkitab dalam Alkitab telah dan harus melalui proses uji yang panjang dan dinyatakan masuk dalam kategori kanonisasi.

Melihat kenyataan tersebut maka tidak jarang keberadaan Kitab Yakobus menimbulkan polemik berkaitan dengan

\footnotetext{
3 The Old Latin merupakan sebuah terjemahan Alkitab Perjanjian Baru sebelum tahun $200 \mathrm{M}$, dan dikenal sebagai Alkitab Gereja Barat. Dalam The Old Latin, semua kitab Perjanjian Baru tercantum di dalamnya, kecuali Kitab Ibrani, Kitab Yakobus, Kitab 1 Petrus dan 2 Petrus. Hal tersebut sama dengan The Muration Canon.
}

keabsaannya dalam kitab-kitab yang termasuk dalam Alkitab. Selain tidak ditemukannya dalam versi Alkitab sebagaimana disebutkan di atas, Kitab Yakobus juga tidak tampak dalam terjemahan Alkitab bahasa Latin Vulgata. ${ }^{4}$ Padahal terjemahan Alkitab Vulgata merupakan salah satu terjemahan Alkitab yang dianggap penting karena akurasi penerjemahannya dan dianggap memiliki sifat otoritas yang cukup dihargai banyak gereja.

Selanjutnya pada tahun 325 , ada seorang cendekiawan Kristen yang bernama Eusebius ${ }^{5}$ memasukkan Kitab Yakobus dalam daftar kitab yang disusunnya. Tentunya hal tersebut tidaklah dilaluinya dengan mudah, sebab ada banyak pihak yang mempersoalkannya. Namun demikian, walaupun masih banyak perdebatan akan keberadaan kitab Yakobus, justru Gereja Timur $^{6}$ telah

\footnotetext{
4 Paus Damasus I ingin supaya bahasa Latin menjadi bahasa penting bagi gereja sehingga ia berupaya menerjemahkan Alkitab ke dalam bahasa Latin. Pada tahun 382, beliau meminta supaya Hieronimus atau Jerome (347-420) untuk melakukan penerjemahan tersebut dan terjemahan yang dimaksud selesai pada tahun 405. Alkitab hasil terjemahan tersebut lalu dikenal sebagai Vulgata.

${ }^{5}$ Eusebius (275-339) adalah uskup di Kaisarea, dan dalam catatan sejarah gereja Katolik, ia tercatat sebagai Paus ke-31. Eusibius adalah seorang teolog yang mahir dalam penafsiran Alkitab, serta seorang ahli sejarah gereja. Ia menjadi salah satu tokoh penting dalam Konsili Nicea yang diselenggarakan pada tahun 325 .

Diduga kuat karena masalah organisasi, kepemimpinan dan juga doktrinal maka sekitar tahun 600-an terjadilah pemisahan gereja antara
} 
menyatakan menerima kitab itu sebagai bagian dari Alkitab.

Kitab Yakobus terus mengalami ujian dalam hal kanonisasi, yaitu ketika reformator Martin Luther menganggap kitab tersebut sebagai straw epistle. ${ }^{7}$ Kitab Yakobus dipandang sebagai sebuah kitab yang tidak memiliki nilai rohani yang memungkinkan kitab tersebut lolos kanonisasi. Itulah sebabnya dengan keraguan atas otoritas kitab tersebut, Martin Luther berkata: Therefore St. James' Epistle is really an epistle of straw, compared to them; for it has nothing of the nature of the Gospel about it. ${ }^{8}$

Bagi Martin Luther kitab Yakobus merupakan kitab jerami karena dianggapnya sebagai kitab yang tidak memiliki sifat Injil di dalamnya. Walaupun Luther masih tetap menganggap Kitab Yakobus sebagai sebuah kitab yang baik sebagaimana kitab-kitab yang ada sebelumnya, namun pernyataannya itu mengundang banyak perdebatan yang lebih mengarah pada ketidaksetujuan atas

timur dan barat. Bahkan pemisahan tersebut secara resmi dinyatakan pada tahun 1200 . Gereja Timur atau yang juga disebut Gereja Ortodoks Timur berpusat di Konstantinopel, dan gereja Barat di Roma. Gereja Ortodoks Timur berpegang pada pemerintahan gereja Episkopal, di mana pemimpinnya adalah uskup atau Patriakh Konstantinopel.

7 Straw Epistle adalah sebutan untuk Kitab Yakobus, yang dinyatakan sebagai kitab jerami, karena Martin Luther menilai Kitab Yakobus sebagai kitab yang terlalu praktis.

${ }^{8}$ Lihat penjelasan Charles M. Jacobs, Works of Martin Luther (Philadelphia: Muhlenberg Press, 1932), 443-444. pernyataan yang dimaksud. Sudah pasti bahwa pemahaman Luther tersebut kuranglah tepat karena ia tidak melihat Kitab Yakobus secara utuh. Walaupun pernyataan Luther mengundang pro dan kontra, namun pernyataan tersebut setidaknya memberikan sebuah peringatan bahwa Kitab Yakobus pernah mengalami ujian yang cukup berat berkaitan dengan proses kanonisasinya. Jika Luther menyelidiki kitab ini dengan baik dan menyeluruh, maka pastilah pemahamannya mengenai salah satu kitab penting dalam Perjanjian Baru, khususnya kelompok kitab surat-surat umum akan menjadi lain.

\section{Penulis Kitab Yakobus}

Jika memperhatikan Yakobus 1:1, maka diketahui dengan pasti bahwa sesungguhnya penulis kitab ini ialah seorang yang bernama Yakobus. Namun demikian, ketika nama ini disebut sebagai penulis Kitab Yakobus, maka akan menjadi persoalan tersendiri karena ada beberapa orang yang memiliki nama yang sama. Alkitab memberikan informasi bahwa setidaknya ada beberapa orang yang memiliki nama Yakobus, sebagaimana diungkapkan dalam beberapa ayat dalam kitab-kitab Perjanjian Baru (lihat Mat. 4:10-22; Luk. 6:15; Mrk. 2:14; Mat. 13:55).

Ada seorang yang bernama Yakobus, yang merupakan murid Tuhan 
Yesus dan ia juga disebut sebagai Yakobus anak Zebedeus. Berkaitan dengan dugaan bahwa Yakobus anak Zebedeus yang menjadi penulis Kitab Yakobus agak sulit diterima karena sejarah telah mencatat bahwa murid Yesus ini mati terbunuh di tangan Herodes pada tahun $42 \mathrm{M}$ (lih. Kis. 12). Sementara itu, sejumlah ahli berpendapat bahwa kitab Yakobus ditulis antara tahun 45-49 M. Selain itu, Yakobus anak Zebedeus menjadi murid pertama yang menjadi martir di Yerusalem. Dengan demikian maka dugaan bahwa Yakobus anak Zebedeus sebagai penulis Kitab Yakobus sangatlah tidak mungkin.

Ada juga seorang murid Yesus yang lain bernama Yakobus. Akan tetapi orang mengenalnya dengan sebutan Yakobus anak Alfeus. Murid Yesus ini tidak terlalu menonjol dalam kisah kehidupan dan pelayanan Yesus Kristus, bahkan para rasul di zaman gereja mulamula, sehingga namanya jarang disebutkan dalam Perjanjian Baru (lih. Mat. 10:3; Mrk. 3:18; Luk. 6:15; Kis. 1:13). Banyak ahli kitab yang memberikan kesan bahwa Yakobus anak Alfeus merupakan orang yang sama dengan Yakobus saudara Yesus. Tentunya hal ini memiliki alasan yang kuat, karena salah satu orang yang berpandangan demikian adalah seorang yang bernama Hieronimus. ${ }^{9}$ Pandangan ini diterima luas oleh Gereja Katolik Roma. ${ }^{10}$ Namun demikian, kebanyakan Gereja Ortodoks Timur $^{11}$ dan Gereja Kristen setelah reformasi pada umumnya cenderung menganggap bahwa keduanya merupakan orang yang berbeda satu dengan lainnya. Nama Alfeus juga disebutkan dalam Alkitab sebagai ayah dari Lewi, yang merupakan seorang pemungut cukai yang kemudian menjadi murid Yesus (lihat Mrk. 2:14), dan pemungut cukai yang dimaksudkan tersebut dinyatakan dalam Kitab Matius sebagai seorang yang bernama Matius

9 Hieronimus (347-420) juga dikenal dengan sebutan Jerome dan merupakan tokoh penting dalam kajian sejarah gereja. Dia dianggap berjasa karena karya terjemahan Alkitab Vulgata yang dikerjakannya. Dia juga dikenal sebagai seorang yang membela Doktrin Gereja Katolik tentang Keperawanan Maria, melalui bukunya yang berjudul the perpetual virginity of blessed Mary; against Helvidius.

${ }^{10}$ Istilah Gereja Katolik untuk pertama kalinya diperkenalkan oleh Ignatius dari Antiokhia pada tahun 107, yaitu ketika ia menguraikannya dalam suratnya kepada jemaat di Smirna. Dalam surat tersebut, Ignatius menyatakan bahwa Gereja Katolik sebagai satu-satunya gereja yang didirikan oleh Yesus Kristus. Pernyataan Ignatius tersebut sebagai upaya untuk membedakan gereja dengan bidat.

${ }^{11}$ Gereja Orthodox Timur juga dikenal juga sebagai Gereja Katolik Ortodoks dan merupakan kelompok gereja yang menerima hasil Konsili Kalsedon namun tetap menolak otoritas Paus. Kepala Gereja Ortodoks Timur adalah seorang Patriarkh atau Uskup yang memiliki kewenangan sebagai koordinator gereja-gereja yang ada di setiap negara, dan ia bukanlah wakil Yesus Kristus, tetapi dipandang sebagai kepala tituler dan gereja. Pada tahun 1054 kekristenan terbagi menjadi Gereja Roma Katolik yang berpusat di Roma dan Gereja Ortodoks Timur yang tadinya berpusat di empat keuskupan, yaitu: Alexandria, Antiokia, Konstantinopel, dan Yarusalem, namun pada akhirnya berpusat di Konstantinopel. 
(lihat Mat. 9:9), juga kisah pemungut cukai yang dimaksudkan tersebut tercatat dalam kitab Lukas dengan sebutan Lewi (lihat Luk. 5:27); sehingga Lewi yang adalah anak Alfeus ini sesungguhnya adalah Matius. Dengan demikian ada dugaan yang cukup kuat bahwa sesungguhnya Yakobus anak Alfeus ini merupakan saudara dari Matius. Berkaitan dengan penulisan Kitab Yakobus, tampaknya Yakobus anak Alfeus tidak terlalu diperhitungkan sebagai penulis kitab tersebut.

Yakobus yang lainnya adalah Yakobus yang oleh Rasul Paulus disebut sebagai Yakobus, saudara Tuhan Yesus (lihat Gal. 1:19). Orang inilah yang diduga kuat sebagai penulis kitab Yakobus. Sesungguhnya tidak perlu berpolemik panjang dalam menentukan siapakah sesungguhnya yang menjadi penulis Kitab Yakobus sebab para ahli lebih condong untuk menyatakan bahwa penulis Kitab Yakobus adalah Yakobus saudara Yesus (band. Mrk. 6:3; Kis. 15:13). Yakobus saudara Yesus diyakini baru menjadi percaya setelah kebangkitan Yesus dari antara orang mati (lihat 1 Kor. 15:7), dan hal ini merupakan salah satu alasan kuat untuk menyatakan bahwa ia bukanlah pribadi yang sama dengan Yakobus anak Alfeus. Menurut tradisi gereja yang dipercaya hingga kini menyatakan bahwa Yakobus merupakan pemimpin Kristen dari golongan Yahudi di Yerusalem, dan oleh Paulus dianggap sebagai sokoguru (lihat Gal. 2:9), bahkan Yakobus saudara Yesus ini diakui memiliki peranan penting dalam sidang Yerusalem (lihat Kis.15:13; Gal. 2:9).

Dugaan kuat bahwa penulis Kitab Yakobus adalah Yakobus yang merupakan saudara Yesus juga perlu dikaji lebih mendalam mengingat pemikiran yang lain dapat muncul karenanya. Itulah sebabnya keyakinan Yakobus saudara Yesus sebagai penulis Kitab Yakobus dapat dipertimbangkan melalui beberapa pendapat yang berkaitan dengan hubungan persaudaraan tersebut, yaitu:

Pertama, ada yang berpandangan bahwa Yakobus adalah saudara kandung Yesus karena merupakan anak Yusuf dan Maria. Janganlah lupa terhadap seorang yang bernama Helvidius ${ }^{12}$ yang pada tahun 380 mencoba untuk mempertanyakan doktrin Keperawanan Maria yang diyakini secara luas oleh Gereja Katolik kala itu. Atas apa yang dilakukan Helvidius tersebut, maka ia menerima reaksi dan bahkan perlawanan yang cukup keras

${ }^{12}$ Helvidius adalah seorang penulis yang oleh Hieronimus dianggap sebagai orang gila yang tidak memahami Injil (lihat Alfred McBride, Images of Mary (Jakarta: Obor, 2004), 106). Helvidius mempertanyakan doktrin Keperawanan Maria yang dipercayai oleh Gereja Katolik, dan akibatnya ia dinyatakan sebagai bidat oleh gereja. Bahkan Hieronimus melawan pemikiran Helvidius melalui karya tulisnya yang berjudul the Perpetual Virginity of Blessed Mary; Against Helvidius. 
karena apa yang diperbincangkannya itu dipandang tidak patut. Helvidius akhirnya dianggap sesat karena memperbincangkan doktrin yang merupakan keyakinan Gereja Katolik yang bersifat absolut dan tidak bisa dipersoalkan oleh siapapun. Gugatan Helvidius perlu dicermati lebih mendalam sebab pertanyaan yang ia sampaikan berkaitan dengan Keperawanan Maria menjadi hal yang menarik untuk diperiksa, untuk pertanyaan berikut, yaitu: Apakah yang berkaitan dengan konsep anak dara sebagaimana yang dinubuatkan dalam Perjanjian Baru? ataukah pertanyaan tersebut memang ditujukan secara khusus pada doktrin Keperawanan Maria yang diyakini Gereja Katolik? Polemik tentang Maria telah berlangsung sejak lama karena wanita inilah yang dipakai Tuhan untuk melahirkan Yesus Kristus. Hirarki keluarga telah menempatkan Yesus sebagai anak dalam keluarga Yusuf dan Maria, dan tentunya hal tersebut semakin memperjelas tentang status Yesus Kristus.

\section{Doktrin Keperawanan Maria} tercantum dalam Konsili Lateran ${ }^{13}$ dan

13 Konsili Lateran yang diselenggarakan pada tahun 649 berhasil membuat rumusan penting doktrin Keperawanan Maria. Sebelumnya dalam Konsili Konstantinopel II tahun 553 menyebutkan bahwa Bunda Maria sebagai kudus, mulia dan tetap perawan. Doktrin ini lebih ditegaskan melalui Pengajaran Magisterium Gereja Katolik. Secara defintif, Paus Martinus I dalam Sinode Lateran menyatakan bahwa: "Maria yang tetap perawan dan tak bernoda yang terberkati, mengandung tanpa benih manusia, oleh Roh Kudus, dan tanpa kehilangan keutuhan melahirkan Dia dan diajarkan secara turun-temurun dari generasi ke generasi. Doktrin ini juga tampak dengan jelas dalam Katekismus Gereja Katolik No. 499. ${ }^{14}$ Lepas dari gugatan Helvidius sehubungan dengan konsep keperawanan Maria, pendapat bahwa Yakobus yang menulis Kitab Yakobus adalah saudara kandung Yesus karena merupakan anak Yusuf dan Maria, telah diterima secara luas di kalangan gereja hingga kini.

Kedua, pendapat yang menyatakan bahwa Yakobus adalah saudara tiri Tuhan Yesus yang merupakan buah perkawinan Yusuf dengan seorang perempuan lain, sebelum ia menikahi Maria, Ibu Yesus. Pemahaman ini didasari pada kitab Apokrifa, Injil Yakobus ${ }^{15}$ menyatakan

sesudahnya tetap perawan. Maka, seperti Kristus yang bangkit dengan tubuh-Nya dapat menembus pintu-pintu rumah yang terkunci (Yoh. 20: 26), maka pada saat kelahiran-Nya, Ia pun lahir dengan tidak merusak keperawanan ibu-Nya, yaitu Bunda Maria."

14 Katekismus Gereja Katolik No. 499 merupakan bagian dari Katekismus Gereja Katolik yang disahkan Paus Yohanes Paulus II dan telah diterbitkan sebagai dokumen resmi gereja pada tanggal 11 Oktober 1992. Pada topik "Dikandung dari Roh Kudus, Dilahirkan oleh Perawan Maria" dalam Katekismus 484-512 Pasal 2, dikatakan: "Pengertian imannya yang lebih dalam tentang keibuan Maria yang perawan, menghantar Gereja kepada pengakuan bahwa Maria dengan sesungguhnya tetap perawan, juga pada waktu kelahiran Putera Allah yang menjadi manusia. Oleh kelahiran-Nya Puteranya tidak mengurangi keutuhan keperawanannya, melainkan justru menyucikannya" (LG 57). Liturgi Gereja menghormati Maria sebagai yang selalu perawan (Aeiparthenos).

${ }^{15}$ Injil Yakobus tidak sama dengan Kitab Yakobus. Injil Yakobus termasuk dalam kelompok kitab-kitab Aprokrifa, yang banyak disinggung dalam tulisan-tulisan Klemens dari Alexandria dan 
bahwa Yusuf adalah seorang duda beranak sebelum menikah dengan Maria. Keyakinan ini dipegang oleh Gereja Yunani $^{16}$ sampai hari ini. Walaupun ada dua pendapat yang sedikit berbeda sebagaimana yang sudah diuraikan tersebut diatas, namun hal penulis kitab Yakobus, yang menunjuk pada Yakobus saudara Yesus nampaknya jelas. Jadi keduanya percaya bahwa penulis kitab Yakobus bukanlah Yakobus anak Zebedeus dan Yakobus anak Alfius.

Pandangan yang ketiga adalah pendapat yang menyatakan bahwa penulis kitab Yakobus adalah seorang yang bernama Yakobus dan ia merupakan "saudara sерирu" Yesus Kristus. Keyakinan ini sesungguhnya dimulai dari pengajaran yang disampaikan oleh

Origenes diakhir abad ke-2 dan juga pada awal abad ke-3, dan diduga telah tersebar luas di kalangan jemaat Kristen pada tahun 150. Injil-injil Apokrifa semacam ini banyak terdapat dalam penemuan di Nag Hammadi, Mesir, dan secara khusus Injil Yakobus, maka sudah pasti bukanlah Yakobus yang menjadi penulis Injil Yakobus karena para melihat bahwa kemungkinan orang non-Yahudi yang menulisnya. Perlu diketahui bahwa manuskrip tertua kitab tersebut ditemukan dalam berbagai bahasa, seperti: bahasa Yunani dan Armenia. Manuskrip dalam bahasa Latin sudah tidak ada karena sejak awal tidak diterima. Terdapat lebih dari 130 manuskrip bahasa Yunani yang masih ada. Pada abad ke-5, Hieronimus menentang injil-injil yang dianggap menyesatkan itu, termasuk Injil Yakobus. Bahkan Martin Luther pun melakukan hal yang sama. Untuk lebih jelasnya dapat membaca buku Deshi Ramadhani yang berjudul, Menguak Injil-Injil Rahasia, terbitan Kanisius, 2007.

${ }^{16}$ Lihat penjelasan footnote 12.
Jerome $^{17}$ pada tahun 383 , yaitu ketika Jerome bereaksi keras sehubungan dengan adanya pihak yang mempersoalkan keyakinan doktrinan Gereja Katolik mengenai konsep keperawanan Maria. Dengan pemikiran tersebut maka alasan Jerome menyampaikan bahwa pemikiran saudara sерири sebagai bagian dari bentuk perlawanan atas ajaran Helvidius yang dianggapnya menyesatkan. Apa yang diyakini Helvidius tentunya dibantah oleh Jerome, sebab ia berkeyakinan bahwa Keperawanan Maria tetap abadi, dan untuk diketahui bahwa sesungguhnya keyakinan Jerome, sejalan dengan pemikiran Augustinus yang percaya akan Perawan Maria yang suci sebagai bagian dari anugerah Tuhan bagi gereja. Pada tanggal 8 Desember 1854, Paus Pius IX mengumumkan Dogma Perawan Maria Dikandung Tanpa Noda atau Ineffabilis Deus. Sungguh menarik untuk memperhatikan doktrin Ineffabilis Deu yang diperkenalkan oleh Gereja Katolik pada waktu itu. Doktrin gereja yang diterima secara utuh oleh jemaat kebanyakan lahir dari pemikiran para pemimpin pada waktu itu. Mereka melakukan kajian dan interpretasi guna mendukung keyakinan teoritisnya. Itulah sebabnya tidak jarang mereka terjerumus

17 Jerome juga dikenal sebagai Eusebius Sophronius Hieronymus atau Hieronimus; dan merupakan orang yang sama. Lihat footnote 10. 
dalam kesesatan doktrinal yang cukup panjang. Gereja pada waktu itu mengajarkan bahwa Maria tetap perawan, sebelum, pada saat dan sesudah melahirkan Yesus.

Walaupun tidak dinyatakan secara eksplisit dalam Kitab Suci, namun hal ini dapat diketahui setidaknya melalui beberapa prinsip, yaitu: Pertama, Allah menguduskan secara istimewa hal- hal yang berkenaan dengan tempat kediamanNya. Kedua, Maria telah mempunyai nazar untuk tetap perawan seumur hidupnya. Ketiga, keperawanan Maria juga melibatkan keperawanan Yusuf suaminya. Keempat, keperawanan Maria inilah yang semakin menunjukkan ke-Allahan Yesus, dan Kelima, Fakta dalam Injil menyatakan bahwa tidak mungkin Maria mempunyai anak-anak lain selain Yesus. Dengan keyakinan tersebut maka konsep tentang Keperawanan Mari yang abadi semakin dikukuhkan dalam kepercayaan iman gereja. Jerome percaya bahwa Keperawanan Maria yang $\operatorname{abadi}^{18}$ dan

18 Apa yang diyakini Jerome tentang Keperawanan Maria yang Abadi adalah anggapan bahwa Maria ibu Yesus mengandung "tanpa kerusakan apapun pada keperawanannya, yang tetap tidak terjamah bahkan setelah kelahiranNya" (lih. Konsili Lateran, tahun 649M). Katekismus Gereja Katolik No. 499 juga menyatakan hal yang sama (lih. footnone 16). Dogma tentang keperawanan Maria yang abadi menurut tradisi Gereja Katolik tersebut telah dibela dan dipelajari dalam tiga bagian, yaitu: virginitas ante partum atau Maria mengandung Yesus; virginitas in partu atau Maria melahirkan Kristus dan virginitas post partum atau Maria tetap bahwa Maria tidak pernah melahirkan anak selain Yesus. Bisa jadi bahwa Yakobus yang dimaksud Jerome adalah Yakobus anak Alfeus; namun mengenai hal ini perlu pembahasan yang lebih mendetail.

Apa yang sudah disampaikan di atas berkaitan dengan siapakah penulis kitab Yakobus, maka penulis mengambil sikap untuk menyatakan bahwa kitab Yakobus ditulis oleh seorang yang bernama Yakobus yang merupakan "saudara Tuhan Yesus" (band. Galatia 1:19). Perhatikanlah dengan baik, yaitu bahwa kalimat "saudara Tuhan Yesus" menjadi hal yang penting untuk dikaji lebih lanjut sebab istilah bahasa Yunani yang dipergunakan untuk kalimat "saudara Tuhan", adalah "adelphos", yang secara harafiah berarti: "dari rahim yang sama".

perawan setelah kelahiran Kristus. Walaupun mendapat banyak penolakan, namun Gereja dalam keyakinan doktrinalnya tetap yakin bahwa Maria adalah perawan selalu. Dogma Maria Virgini yang ditetapkan pada tahun 649 dalam Konsili Lateran di bawah kepemimpinan Paus Santo Martinus I dengan tegas menyatakan bahwa Maria adalah seorang perawan; baik sebelum, selama dan sesudah melahirkan. Bahkan dengan berani Martinus I memaklumkan kanon berikut: "Para Bapa Kudus mengakui bahwa Maria yang kudus dan tetap perawan dan tak bernoda sungguhsungguh dan benar-benar Bunda Allah yang, dalam kegenapan waktu, tanpa benih laki-laki, tetapi berkat Roh Kuduslah, ia mengandung Sang Sabda sendiri, yang sebelum segala waktu telah lahir dari Allah Bapa, dan tanpa kehilangan keperawanannya melahirkan Dia, dan sesudah kelahiran-Nya tetap menjaga keperawanannya tak ternoda; siapa saja yang tidak sepakat dengan ajaran ini, terkutuklah dia." 
Dengan demikian, jika menyatakan bahwa Yakobus itu adalah "sepupuh Tuhan", maka seharusnya kata Yunani yang dipergunakan untuk kalimat tersebut, adalah "anepsios" sebagaimana yang dipergunakan dalam kitab Kolose 4:10 dan Bilangan 36:11. Ingatlah juga bahwa dalam membahas tentang hirarki keluarga dalam kehidupan keluarga Yesus, terdapat ungkapan: "Bukankah Ia ini tukang kayu, anak Maria, saudara Yakobus, Yoses, Yudas dan Simon? Dan bukankah saudara-saudara-Nya yang perempuan ada bersama kita? ..." (Mrk. 6:3). Dari pernyataan tersebut membuktikan bahwa keluarga Yusuf dan Maria masih memiliki anak-anak selain Yesus; tentunya informasi semacam ini masih perlu kajian yang lebih mendalam lagi.

Dengan mempertimbangkan pernyataan tersebut, maka tidaklah salah jika keputusan bahwa Yakobus saudara Yesus merupakan penulis Kitab Yakobus yang sesungguhnya menjadi hal yang wajar untuk dipegang. Berkeyakinan bahwa Yakobus yang merupakan saudara Yesus, sebagai penulis kitab Yakobus telah dipegang banyak pihak sampai sekarang. Berbagai asumsi yang disampaikan merupakan bukti kuat untuk dijadikan dasar pada pemahaman bahwa Yakobus saudara Tuhan Yesus adalah penulis kitab ini. Walaupun tidak menjadi suatu keharusan untuk percaya bahwa
Yakobus saudara Yesus merupakan penulis kitab Yakobus, namun adalah bijak jika mempertimbangkan hal yang telah menjadi tradisi gereja ${ }^{19}$ di mana menyebutkan bahwa Yesus Kristus mempunyai empat saudara kandung pria dan paling sedikit dua saudara kandung wanita.

\section{Latar Belakang Penulisan Kitab Yakobus}

Yakobus adalah pemimpin umat dan karena itulah maka ia merasa berkewajiban untuk memberikan nasehat dan bahkan juga teguran kepada orangorang Kristen yang kebetulan memiliki latar belakang Yudaisme. Pengaruh tradisi dan kepercayaan lama tidaklah mudah terlepas dalam praktek kehidupan seharihari, dan hal tersebut memberi dampak bagi kehidupan iman percaya seseorang. Dengan meperhatikan aspek tersebut, maka ada masalah utama yang dihadapi

19 Tradisi Gereja yang seringkali menjadi dasar pertimbangan dalam kehidupan Gereja Katolik, pada umumnya merupakan kepercayaan atau kebiasaan-kebiasaan baik dengan kata-kata ataupun dengan teladan hidup dari satu generasi ke generasi lainnya tanpa petunjuk tertulis. Dengan kata lain, pemikiran-pemikiran serta nilai-nilai dari satu generasi diwariskan kepada generasi berikutnya. Umat Katolik percaya bahwa gereja senantiasa melestarikan dan meneruskan hidup, ajaran, dan ibadahnya, dari generasi ke generasi. Biasanya ada kurun waktu yang istimewa, yaitu pada zaman Yesus dan para rasul, dan periode yang disebut sebagai Zaman Gereja Perdana atau gereja mula-mula. Dari zaman-zaman inilah, hal-hal yang menjadi tradisi terus digumulkan dalam kehidupan umat dari masa ke masa. 
oleh penerima surat ini, yaitu hubungan antara tradisi keagamaan lama yang sudah mendarah-daging dalam kehidupan keseharian dengan hal kehidupan iman Kristen.

Penerima Kitab Yakobus, mengalami disharmoni dalam kehidupan mereka karena diduga telah terjadi kesalahan fatal dalam mengimplementasikan kehidupan Kristen yang bertanggungjawab. Banyak orang Kristen mengaku telah diselamatkan oleh anugerah Anugerah Tuhan, namun ternyata tidak menjadikan Tuhan sebagai Raja dalam hatinya. Mereka menyatakan diri sebagai orang Kristen yang beriman penuh kepada Kristus, namun tidak mampu menunjukkan pola kehidupan Kristen yang nyata dalam perbuatan kesehariannya. Itulah sebabnya kehadiran Kitab Yakobus setidaknya memberikan sebuah sentuhan yang luar biasa, sehingga setiap orang percaya dituntut bukan hanya sekedar percaya, melainkan mampu menunjukkan kehidupan kepercayaannya dalam kehidupan yang dijalani.

Sangatlah nyata bahwa satu kata antara keyakinan dan perbuatan haruslah menjadi sesuatu yang dapat dinyatakan dalam kehidupan seorang Kristen. Kekristenan tidak seharusnya dipandang sebagai sebuah pengajaran moralitas semata, melainkan sebuah pembuktian hidup bermoral. Bukan hanya berbicara tentang kasih sayang, melainkan bukti kasih. Bukan hanya berbicara iman Kristen namun juga perbuatan Kristen sebagai buah dari iman yang dipercayainya.

\section{Tema Kitab Yakobus}

Secara sederhana, tema kitab Yakobus adalah usaha untuk terus mendorong jemaat guna menerapkan iman yang Kristen sejati. Hidup seorang Kristus haruslah memberikan bukti yang nyata sehingga menjadi berkat bagi mereka yang melihatnya. Sebagaimana dinyatakan dalam ayat berikut, yaitu bahwa: "Ibadah yang murni dan yang tak bercacat di hadapan Allah, Bapa kita, ialah mengunjungi yatim piatu dan janda-janda dalam kesusahan mereka, dan menjaga supaya dirinya sendiri tidak dicemarkan oleh dunia" (Yak. 1:27), maka sesungguhnya iman Kristen haruslah dapat diterapkan dalam kehidupan praktis seharihari.

Yakobus menegur dan menasihati agar sebagai orang percaya, mereka tidak hidup dalam kemunafikan. Ia menegur mereka yang mengaku percaya dan memiliki iman, tetapi pada kenyataannya ternyata imannya mati karena iman tidak terbukti dalam perbuatan (lihat Yak. 2:1417). Selain itu, Kitab Yakobus juga menyinggung hal yang tidak kalah pentingnya, yaitu memberikan kekuatan 
iman melalui pemberian nasehat praktis dalam mengahadapi pencobaan dan penganiayaan.

\section{Tujuan Penulisan Kitab Yakobus}

Surat Yakobus merupakan surat yang ditujukan kepada orang Kristen Yahudi yang tersebar di daerah-daerah perantauan. Mereka adalah petobat baru yang terpaksa harus meninggalkan Yerusalem karena ancaman dan tekanan dari masyarakat Yahudi yang tidak setuju dengan kekristenan pada waktu itu. Itulah sebabnya penulisan kitab ini memiliki beberapa tujuan yang diharapkan mampu menjawab kebutuhan umat yang mendesak, yaitu: Pertama, Yakobus ingin memberikan semangat kepada orang Kristen Yahudi yang mengalami penderitaan karena iman kepercayaannya kepada Kristus. Beberapa pihak tidak setuju dengan keyakinan mereka yang baru, dan berupaya untuk membuat orangorang ini tidak lagi percaya kepada Yesus Kristus. Salah satu hal yang dialami orang Kristen Yaahudi berkaitan dengan keyakinan iman tersebut adalah tekanan yang mereka alami. Penderitaan terjadi dan mereka harus bisa tahan dalam keadaan tersebut. Bagi Yahobus, penderitaan yang dialami umat Allah ini merupakan sebuah ujian bagi mereka. Untuk itulah ia memberikan kekuatan kepada mereka supaya mampu bertahan. Kedua, Yakobus berkeinginan kuat untuk memperbaiki berbagai pengertian yang salah dalam kehidupan orang percaya. Kesalahan yang dimaksud tersebut adalah berkaitan dengan sifat iman yang menyelamatkan. Teologi Kristen sangat jelas berbicara tentang doktrin soteriologi, yaitu keselamatan hanya ada dalam Kristus (band. Yoh. 14:6, Kis. 4:12). Namun demikian, iman yang benar tidak sekedar percaya saja, melainkan disertai dengan tanggung jawab hidup yang benar pula. Seorang yang percaya harusnya menunjukkan hidup yang selayaknya sebagai orang percaya. Inilah yang seringkali diabaikan banyak orang percaya, sebab bagi mereka cukuplah sekedar percaya.

Yakobus hendak menuntun setiap orang percaya untuk hidup secara bertangungjawab dalam kepercayaan iman yang benar di dalam Yesus Kristus. Benarlah perkataan Yesus berikut ini: "Dari buahnyalah kamu akan mengenal mereka. Dapatkah orang memetik buah anggur dari semak duri atau buah ara dari rumput duri? .... jadi dari buahnyalah kamu akan mengenal mereka" (Mat. 7:16, 20). Bagi Yakobus, seorang Kristen bukan hanya dituntut untuk beriman dengan benar, yaitu iman kepada Yesus Kristus, dan juga harus mampu mengimplementasikan iman yang dimaksudkan tersebut dalam kehidupan yang nyata. 
Yakobus menegur dan menasihati penerima suratnya agar mereka sebagai orang percaya tidak hidup dalam kemunafikan. Ia juga menegur mereka yang mengaku memiliki iman, tetapi ternyata bahwa imannya mati karena iman itu tidak terbukti dalam perbuatan (lihat Yak. 2:14-17). Yakobus memperingatkan mereka yang dengan mulutnya memuji Tuhan, tetapi dengan mulut yang sama mengutuki sesamanya (lihat Yak. 3:9-10). Tuntutan yang harus dipenuhi oleh setiap orang yang percaya kepada Kristus, bukan hanya sekedar percaya, melainkan mampu mengimplementasikan iman kepercayaannya dalam kehidupan kesehariannya.

\section{Penerima Kitab Yakobus}

Jika memperhatikan beberapa tafsiran dan bahkan kajian terhadap Kitab Yakobus, maka kebanyakan para ahli percaya bahwa orang Kristen yang berlatarbelakang Yudaisme adalah penerima Kitab Yakobus. Mereka berada di perantauan karena diduga mengalami tekanan di Yerusalem. Yakobus dengan sangat jelas memberikan pernyataan bahwa kitab ini ditujukan kepada keduabelas suku di perantauan (lihat Yak. 1:1). Walaupun masih perlu kajian tentang keberadaan orang percaya di perantauan, namun kemungkinan bahwa kedua belas suku yang dimaksudkan adalah orang- orang Yahudi yang berada di luar Palestina yang kepergian mereka adalah karena penawanan, atau juga karena kemauan mereka sendiri untuk merantau, menjadi hal yang patut diperhatikan. ${ }^{20}$

\section{Tempat dan waktu Penulisan Kitab Yakobus}

Tempat dan waktu penulisan Kitab Yakobus menjadi kajian yang tidak terlalu sulit untuk dibicarakan karena data histroris yang ada memberikan banyak informasi yang jelas mengenai hal tersebut. Para sejarawan dan arkeolog telah melakukan tugas penelitiannya, dan sumber-sumber pustaka memberikan informasi mengenai hal tersebut. Tentunya informasi ini akan menolong banyak pihak yang hendak menyelidiki Kitab Yakobus, khususnya berkaitan dengan waktu dan tempat penulisan yang dimaksud.

Data penelitian telah dipublikasikan oleh pihak-pihak yang melakukan kajian terhadap Kitab Yakobus dan telah memberikan banyak informasi mengenai tempat dan waktu penulisan kitab tersebut. Perlu ditegaskan kembali bahwa banyak kalangan sepakat untuk menyatakan bahwa Kitab Yakobus ditulis di Yerusalem. Penulisan kitab tersebut

20 Hasan Sutanto, Surat Yakobus: Berita Perdamaian yang Patut Didengar (Malang: Departemen Literatur SAAT, 2006), 40. 
diduga dilakukan sebelum terjadinya peristiwa besar yang pernah dinubuatkan Yesus pada waktu hendak masuk kota Yerusalem, yaitu penghancuran kota suci itu (lihat Luk. 19:41-44). Sejarah membuktikan bahwa nubuatan Yesus tersebut tergenapi dengan peristiwa penghancuran kota tersebut pada tahun 70 M oleh Jenderal Titus. ${ }^{21}$ Dugaan bahwa Kitab Yakobus ditulis sebelum peristiwa penghancuran Yerusalem didasarkan pada informasi yang tidak menyinggung peristiwa tersebut. Demikian juga dengan tahun kematian Yakobus yang diduga terjadi sebelum tahun $62 \mathrm{M}$. Kemudian catatan sejarah menyatakan bahwa sekitar tahun 46-51 M telah terjadi penganiayaan yang berat terhadap orang percaya yang berada di kota Yerusalem sehingga mereka terpencar ke daerah-daerah lain di sekitarnya.

${ }^{21}$ Jenderal Titus adalah anak dari Kaisar Vespasianus yang pernah diutus kaisar Nero untuk meredam pemberontakan orang Israel. Pada saat hampir menguasai Yerusalem, Jenderal Vespasianus dipanggil pulang ke Roma karena Nero wafat, dan ia kemudian dilantik sebagai kaisar untuk menggantikan Nero. Penugasan Jenderal Titus untuk merebut Yerusalem dan memadamkan pemberontakan telah membuat Titus mengepung Yerusalem dan terus memerintahkan pasukannya untuk meruntuhkan tembok-tembok. Usaha tentara Romawi tersebut berhasil, dan orang Israel terdesak dan mundur, lalu mereka berlindung di dalam Bait Allah. Kesempatan itu segera dimanfaatkan oleh tentara Romawi dengan mendesak masuk ke dalam dan bahkan membakar gedung yang menjadi tempat peribadatan itu. Walaupun kelompok Zelot bertahan di Masada namun pemberontakan itu gagal. Atas peristiwa itu, orang Kristen di Yerusalem melarikan diri ke Pella di Transyordania (lihat Luk. 21:20-24).
Ada beberapa hal yang perlu dipertimbangkan dalam kajian tahun penulisan kitab ini, yaitu: hal yang berkaitan dengan keanggotaan gereja bagi masyarakat non Yahudi tidak disinggung dalam kitab ini, padahal isu ini telah diselesaikan pada saat pelaksanaan Konsili Yerusalem di tahun $49 \mathrm{M}$. Itu berarti ada kemungkinan bahwa Kitab Yakobus ditulis pada waktu jumlah orang Kristen yang berlatar belakang non-Yahudi belum terlalu banyak. Jadi, kemungkinan besar Kitab Yakobus ditulis oleh Yakobus saudara Yesus Kristus di antara tahun 45 M dan 49 M menjadi hal yang patut diterima.

Pada saat rasul Paulus menyebut Yakobus sebagai sokoguru gereja (band. Gal. 2:9), maka kesan yang muncul di sini adalah posisi Yakobus sebagai pemimpin umat. Janganlah lupa bahwa status sokoguru gereja dalam tradisi gereja Katolik dipandang sejajar dengan Petrus dan Yohanes. Dengan posisinya sebagai pemimpin gereja di Yerusalem, maka kemungkinan besar Yakobus tinggal di kota tersebut dengan jabatan sebagai uskup.

Yakobus dianggap berhasil dalam pelayanan pemberitaan Injil dan hal itu dibuktikan dengan ada banyaknya petobat baru di Yerusalem. Pertobatan yang terjadi di kota itu juga membuat gereja mula-mula mengalami pertumbuhan yang cukup 
signifikan. Tentunya pertumbuhan yang dimaksud mengingatkan banyak pihak tentang pekerjaan Roh Kudus pada gereja pertama ketika peristiwa Pentakosta (lihat Kis. 2-4). Mereka yang telah menjadi percaya kepada Kristus, bukan hanya orang Yahudi saja, melainkan juga sejumlah orang non-Yahudi yang ikut menjadi percaya. Perlu diketahui bahwa kala itu, Yerusalem menjadi pusat perdagangan, studi dan kebudayaan dan pemerintahan kolonial. Dengan demikian, maka kota itu menjadi sentral bertemunya banyak kalangan. Orang-orang nonYahudi yang percaya kepada Kristus merupakan kaum pendatang karena berbagai kepentingan.

Data sejarah yang ada menyatakan bahwa ketika diadakan konsili di Yerusalem $^{22}$ pada tahun $49 \mathrm{M}$ diketahui bahwa ternyata Yakobus sempat berdebat dengan Paulus tentang sejauh mana orangorang Kristen yang bukan keturunan Yahudi harus menghormati beberapa pokok pengajaran dalam Hukum Taurat, dan peserta Konsili Yerusalem mencoba

${ }^{22}$ Konsili Yerusalem tahun 49 merupakan konsili yang membicarakan tentang orang-orang non-Yahudi yang telah percaya kepada Kristus dan kemudian menjadi anggota gereja. Keadaan ini seringkali memancing perdebatan berkaitan status mereka. Itulah sebabnya Konsili Yerusalem mencoba mencari formula penyelesaian, dan akhirnya konsili ini menetapkan syarat penerimaan orang non-Yahudi yang juga disebut sebagai orang kafir, bahwa untuk masuk ke dalam persekutuan gereja, mereka tidak harus menjalani aturan hukum Taurat. untuk merumuskan formula baru mengenai keanggotaan gereja non-Yahudi tersebut. Pada akhirnya disepakati sebuah sebutan yang akhirnya menjadi sebuah istilah populer untuk menyebut orang Kristen yang bukan keturunan Yahudi dengan sebutan Gentiles. $^{23}$

Sejarah gereja mencatat bahwa telah dilaksanakan sebuah persidangan gereja di Yerusalem di mana Persidangan Yerusalem itu membahas masalah sunat dan keselamatan, dan hasil keputusan konsili tersebut menyatakan bahwa orang non-Yahudi yang telah percaya kepada Yesus tidak perlu lagi disunat, akan tetapi aturan taurat tetap berlaku dan harus diikuti oleh mereka. Yakobus yang tinggal di Yerusalem kemudian menulis surat untuk orang Kristen yang telah tersebar di mana-mana. Bahkan setelah peristiwa penghancuran Yerusalem, lebih banyak lagi orang Kristen yang tersebar ke berbagai daerah.

Yosefus $^{24}$ seorang ahli sejarah Yahudi yang banyak menulis tentang

${ }^{23}$ Gentiles merupakan sebutan untuk orang Kristen non-Yahudi. Istilah ini menunjuk kepada kelompok orang yang tidak termasuk hitungan Yahudi atau dalam istilah sehari-hari adalah orang yang seharusnya tidak menerima perjanjian. Kata Gentiles itu sendiri berarti orang kafir. Orang Kristen non-Yahudi seringkali disebut sebagai kelompok Messianic Gentiles, yaitu kelompok orang kafir yang sudah menerima keselamatan dan masuk ke dalam perjanjian Abraham atau menjadi Israel rohani.

${ }^{24}$ Yosefus atau Flavius Yosefus yang juga dikenal sebagai ben Yosef Matityahu merupakan seorang sejarawan yang banyak mencatat peristiwa 
peristiwa-peristiwa pada masa gereja mula-mula menyampaikan bahwa Ananus, imam besar Saduki bertanggungjawab atas kematian Yakobus yang menurut tradisi gereja dirajam sampai mati setelah sebelumnya saudara Yesus itu dilempar dari atap Bait Allah. Tentunya dalam banyak catatan mengenai peristiwa tersebut memberikan kesan bahwa bagaimana Yakobus dengan berani menyatakan iman percayanya, walaupun ia harus menanggung resiko yang sedemikian berat itu.

Sejarah mencatat bahwa peristiwa Yakobus menjadi martir tersebut terjadi setelah kematian Festus $^{25}$ seorang prokurator Romawi yang kemudian jabatan tersebut dipegang oleh

penting dalam kehidupan masyarakat Yahudi dan warga negara Romawi. Salah satu catatan penting yang dibuatnya adalah peristiwa penghancuran Yerusalem pada tahun 70. Penulis sejarah yang menguasai bahasa Aram, Ibrani dan Yunani ini juga dikenal dekat dengan penguasa Romawi, bahkan dia masuk dalam klan Flavianus, yang membuatnya dikenal sebagai Flavius Yosefus, dan justru dalam perlindungan pemerintah Romawi-lah yang membuatnya dengan leluasa menulis berbagai karyanya yang terkenal itu. Banyak buku yang sudah ditulisnya, diantaranya adalah: War of the Jews, atau History of the Jewish War (thn. 75), Josephus's Discourse to the Greeks concerning Hades (spurious; adaptation of "Against Plato, on the Cause of the Universe" by Hippolytus of Rome), Antiquities of the Jews (thn. 94), Against the Greeks, on the antiquity of the Jewish people (thn. 97), dan Autobiography of Flavius Josephus (thn. 99).

${ }^{25}$ Setelah kematian prokurator Romawi, Antonius Feliks, maka kekaisaran Romawi menunjuk Perkius Festus sebagai penggantinya, dan ia menjadi prokurator Romawi untuk wilayah Yudea pada tahun 59-62. Beberapa ahli kitab menyatakan bahwa ia terlibat dalam mengadili Paulus. penggantinya yang bernama Albinus. ${ }^{26}$ Logikanya jika kematian Festus yang tercatat dalam sejarah, terjadi pada tahun 62, maka kemungkinan besar Kitab Yakobus ditulis sebelum tahun tersebut. Dengan demikian beberapa ahli yang berpendapat bahwa Kitab Yakobus ditulis antara tahun 45-49 sudah tepat.

\section{Kanonisasi Kitab Yakobus}

Sebagaimana telah disinggung pada bagian sebelumnya, hal kanonisasi atas kitab Yakobus mengalami kendala dari masa ke masa. Yakobus mengalami masa-masa yang sulit karena sepertinya tidak diakui. Hal tersebut berkaitan dengan julukan yang diberikan kepada kitab ini, yaitu sebagai "kitab jerami". Namun juga tidak bisa mengabaikan fakta tentang adanya pengakuan bahwa Kitab Yakobus merupakan kitab yang memiliki legitimasi dalam aspek kanonisasi.

Proses kanonisasi Perjanjian Baru didasari pada kitab-kitab yang ditulis oleh para rasul dan hal itu dilakukan karena kebanyakan gereja percaya bahwa kitabkitab tersebut merupakan kitab yang diinspirasikan Allah. Tentunya tidaklah sembarangan dalam penetapan sebuah

\footnotetext{
${ }^{26}$ Lucceius Albinus menjadi prokurator Romawi di Yudea di tahun 62-64 setelah Festus. Selesai bertugas di Yudea, Albinus ditetapkan menjadi gubernur di koloni kekaisaran Roma lainnya pada tahun 64-69.
} 
kitab sebagai bagian dari Alkitab kanonisasi.

Pada saat terjadi penganiayaan terhadap kekristenan yang dilakukan Kaisar Diokletianus ${ }^{27}$ pada tahun $303 \mathrm{M}$, ada begitu banyak Alkitab terbakar, dan hal itu memaksa para pemimpin gereja pada masa itu untuk kembali memilih, meneliti dan bahkan menetapkan kanon Perjanjian Baru. Sesungguhnya pada abad ke-2, kanon Perjanjian Baru telah lengkap. Masa sulit itu harus dilalui setiap orang percaya yang tinggal di wilayah kekuasaan Diokletianus.

Galerius, panglima perang kaisar Diokletianus dianggap kuat mempengaruhi sang kaisar untuk mengeluarkan suatu keputusan penting yang dikenal sebagai edik Diokletianus pada tahun 303 M. Dengan dikeluarkannya ketetapan tersebut, maka tindakan penganiayaan terhadap orang Kristen dianggap memiliki dasar dan kekuatan hukum. Akibatnya, kekristenan secara resmi dilarang, gereja dibakar, Alkitab harus diserahkan untuk dimusnahkan dan orang-orang Kristen dipaksa untuk meninggalkan iman

\footnotetext{
${ }^{27}$ Kaisar Diokletianus adalah kaisar Romawi yang memerintah pada tahun 284 hingga 305 . Ketika Carus dan anaknya, Numerian tewas dalam sebuah pertempuran di Persia maka Diokletianus menjadi kaisar setelah Carinus yang juga memiliki ambisi dikalahkannya. Selama masa pemerintahannya, Diokletianus mampu menjaga kestabilan roda pemerintahannya. Sayangnya ia terlibat dalam penganiayaan orang Kristen dan juga aksi pembakaran Alkitab.
}

kepercayaannya. Sejarah mencatat bahwa penganiayaan atas diri orang percaya terus berlanjut dan bahkan semakin para ketika Galarius tampil menggantikan Diokletianus. Bersyukur bahwa penganiayaan itu berhenti seiring dengan tampilnya Gaius Flavius Valerius Aurelius Konstantinus (272-337) ${ }^{28}$ atau yang juga dikenal sebagai Kaisar Konstantinus. Sejarah gereja mencatat bahwa beliau menjadi orang Kristen dan akhirnya mengeluarkan edik Milano ${ }^{29}$ pada tahun 313, yang pada pokoknya menyatakan agama Kristen sebagai agama yang legal di seluruh kekaisaran Roma. Dengan dikeluarkannya dekrit tersebut, maka secara otomatis kekristenan mendapat kesempatan yang baik untuk mengembangkan diri seluar-luasnya.

\footnotetext{
28 Gaius Flavius Valerius Aurelius Constantinus (272-337) adalah kaisar Romawi yang dianggap berjasa karena menerbitkan edik Milano, yang secara hukum menjadikan agama Kristen sebagai agama yang diakui di seluruh wilayah kekaisarannya. Bahkan ia sendiri menjadi pemeluk agama Kristen dan terlibat dalam penyelenggaraan Konsili Nicea Pertama tahun 325. Konstantinus diakui gereja sebagai orang yang berjasa besar dalam sejarah perkembangan gereja, dan bahkan dihormati sebagai santo oleh orang-orang Kristen Ortodoks Timur, Gereja Katolik, dan bahkan Gereja Anglikan.

${ }^{29}$ Edik Milano atau yang dikenal sebagai Dekrit Milan dikeluarkan pada tahun 313 di mana kekaisaran Romawi menunjukkan sikap bersahabat dengan agama Kristen. Kaisar Konstantinus mengubah kebijakan terhadap agama Kristen. Dokumen yang dikenal juga disebut sebagai Edictum Mediolanense memberikan kebebasan beragama, dan ketika itu sangat menguntungkan agama Kristen karena di kemudian hari agama Kristen menjadi agama resmi yang diakui sebagai agama negara.
} 
Tentunya kesempatan ini dipergunakan oleh gereja tadinya mengalami tekanan yang luar biasa. Dengan dekrit tersebut, maka agama Kristen terus berkembang dan bahkan legalitasnya diakui di seluruh kekaisaran Romawi.

Selanjutnya pada tahun 367, sebuah tulisan yang dikenal masyarakat luas, menjadi objek pembahasan yang banyak orang; dimana tulisan yang dikenal sebagai Festal Letter $^{30}$ menjadi bahan perbincangan. Tulisan yang ditulis oleh Athanasius $^{31}$ tersebut mencantumkan ke27 kitab Perjanjian Baru yang tentunya sangat membantu dalam dukungan legalitas kitab-kitab Perjanjian Baru.

Kanonisi Perjanjian Baru menjadi hal yang sangat penting ketika Jerome dan Agustinus $^{32}$ mengakui kanonisasi Perjanjian Baru, dan akhirnya diikuti oleh

30 Festal Letter atau yang dikenal sebagai Surat Paskah yang ditulis oleh Uskup Alexandria, Athanasius, di mana salah satu kebiasaan beliau yang suka menulis setelah Minggu Epiphania. Surat-surat tersebut dikirim ke gereja-gereja dan biara-biara di Mesir; yang merupakan wilayah tanggung jawab pelayanannya.

31 Athanasius (293-373) adalah seorang teolog, apologet dan pemimpin nasional yang merupakan salah satu tokoh penting dalam sejarah gereja, karena ia dikenal begitu keras melawan para bidat yang dianggapnya dapat merusak pekerjaan dan pelayanan gereja. Pada tahun 328, Athanasius diangkat menjadi uskup Alexandria. Ia juga tampil menjadi orang penting dalam Konsili Nicea tahun 325.

32 Agustinus (354-430) atau yang juga dikenal sebagai Aurelius Agustinus atau Agustinus Hippo adalah seorang tokoh penting dalam sejarah gereja. Ia diakui sebagai salah satu tokoh terpenting dalam perkembangan Kekristenan Barat. Gereja menganggapnya sebagai salah satu sumber pemikiran teologi Kristen, khususnya aliran berkaitan dengan keselamatan dan anugerah. kebanyakan gereja pada masa tersebut. Perlu diketahui bahwa pada masa itu, gereja telah menerima kitab-kitab dalam Alkitab sebagai firman Allah yang memiliki otoritas tertinggi. Pada akhirnya gereja mengakui ke-27 kitab sebagai kanon Perjanjian Baru dan ke-39 Kitab sebagai kanon Perjanjian Lama setelah terjadi Konsili Hippo tahun $393 \mathrm{M}^{33}$ dan Konsili Kartago I tahun 397 M $^{34}$ yang menegaskan kembali hasil dari konsili sebelumnya, yaitu Konsili Hippo.

Kanonisasi Perjanjian Lama telah terjadi untuk pertama kalinya pada masa pemerintahan raja Yosia, yaitu tahun 622 $\mathrm{BC}$, di mana peristiwa ini dikenal sebagai Gerakan Reformasi Deuteronomis. Apa yang dilakukan Yosia ini dianggap berhasil karena mampu mengumpulkan berbagai sumber sehingga menjadi satu kumpulan Taurat yang terdiri atas lima kitab Musa. Selanjutnya kitab para nabi

\footnotetext{
${ }^{33}$ Konsili yang dilaksanakan di kota Hippone atau Hippo Regius yang terletak di Afrika Utara (sekarang masuk wilayah kedaulatan Aljazair); pada tahun 393 dikenal sebagai Konsili Hippo. Konsili ini merupakan momentum penting bagi gereja karena untuk pertama kalinya para pemimpin gereja menyusun daftar kitab yang sudah diakui dalam proses kanonisasi dan bahkan menyetujuinya. Daftar kita yang disetujui tersebut sama dengan daftar kitab dalam Alkitab saat ini.

34 Konsili Kartago I tahun 397 di Afrika Utara diselenggarakan untuk menyetujui dan menetapkan kanon Perjanjian Lama dan Perjanjian Baru sebagaimana yang sudah disahkan dalam Konsili Hippo. Gereja Kristen menganggap pelaksanaan konsili ini sebagai yang menentukan secara otoritatif kanon Perjanjian Baru. Gereja Kristen menganggap bahwa konsili ini sebagai otoritatif bagi kanonisasi kitab-kitab dalam Perjanjian Baru.
} 
atau nevi'im ditambahkan kemudian oleh para imam.

Kitab-kitab dalam Perjanjian Baru ditulis sekitar tahun 50-100 dan setelah itu barulah terjadi proses kanonisasi atas kitab-kitab yang dimaksudkan tersebut. Berkaitan khusus dengan kanonisasi kitab Yakobus sesungguhnya pada abad ke-4 dan ke-5, kitab ini telah tercantum pada beberapa naskah kuno Alkitab, di antaranya: naskah kuno yang dikenal sebagai Manuskrip Vatikanus No. 1209, ${ }^{35}$ Manuskrip Sinaitikus ${ }^{36}$ dan Pesyita Siria ${ }^{37}$

35 Manuskrip Vatikanus No. 1209 juga dikenal sebagai Codex Vaticanus, dan merupakan salah satu naskah manuskrip Alkitab tertua yang masih ada dan menjadi naskah penting dalam sejarah tekstual Alkitab. Naskah yang tersimpan di perpustakaan Vatikan ini dianggap sedikit lebih tua daripada Codex Sinaiticus. Manuskrip ini berisi salinan lengkap dari Perjanjian Lama (Septuaginta) dan Perjanjian Baru.

${ }^{36}$ Konstantin von Tischendorf, seorang ahli linguistik Jerman melakukan ekspedisi ke Timur Tengah guna mencari manuskrip kuno Alkitab pada tahun 1859 dan menemukan salinan lengkap Manuskrip Sinaitikus di kaki Gunung Sinai. Manuskrip ini diduga dibuat sekitar 50 tahun sebelum Alkitab terjemahan Vulgata selesai dikerjakan. Manuskrip ini merupakan salah satu manuskrip tertua dalam bahasa Ibrani. Dapatlah dikatakan bahwa Manuskrip Sinaitikus menjadi acuan atas naskah-naskah lainnya.

${ }^{37}$ Pesyita Siria adalah Alkitab terjemahan dalam bahasa Siria. Istilah Pesyita berarti sederhana atau jelas, memberikan gambaran mengenai terjemahan yang dimaksud dan merupakan salah satu bukti tertua dan terpenting dari penyalinan naskah Alkitab. Pada abad ke-2, ada banyak orang Kristen yang berbahasa Siria, sehingga dipandang perlu untuk menerjemahkan Alkitab ke dalam bahasa mereka, dan seorang yang bernama Tatianus (120-173), penulis Siria di tahun 170, menggabungkan keempat Injil dalam Yunani ataupun bahasa Siria, yang dikenal sebagai Diatessaron. Kemudian Efraem (310-373) seorang Siria, berhasil membuat ulasan tentang Diatessaron, yang banyak digunakan oleh gereja berbahasa di mana naskah-naskah tersebut sesungguhnya telah memberikan informasi yang cukup baik mengenai kitab Yakobus.

Informasi yang dapat mendukung aspek orsinilitas Kitab Yakobus tidak hanya sebatas pada naskah-naskah yang sudah disebutkan di atas, melainkan ada juga naskah kuno lainnya, yaitu Manuskrip Aleksandrinus. ${ }^{38}$ Bahkan dalam penelitian arkeologis, hingga kini terdapat lebih dari sepuluh katalog kuno yang ditemukan, sesungguhnya telah mencantumkan Kitab Yakobus sebagai bagian dari Alkitab Perjanjian Baru.Tentunya dengan berbagai hal yang dijalaninya, akhirnya pengesahan Kitab Yakobus sebagai bagian dari Alkitab dilakukan melalui Konsili Kartago.

\section{Kehidupan Yakobus Sebagai Penulis} Kitab Yakobus

Sebagaimana yang telah diuraikan di atas bahwa Yakobus saudara Yesus adalah penulis Kitab Yakobus. Tentunya

Siria. Beberapa kalangan berpendapat bahwa terjemahan ini meragukan.

${ }^{38}$ Manuskrip Aleksandrinus yang sekarang ini tersimpan dengan baik bersama-sama Codex Sinaiticus di kotak kaca Ritblat Gallery, British Library. Tulisan ini diperkirakan ditulis pada abad ke-5 yang di dalamnya memuat seluruh kitab dalam Alkitab. Manuskrip Aleksandrinus yang juga bernama Codex Alexandrinus ini merupakan naskah Alkitab bahasa Yunani yang memuat sebagian besar Perjanjian Lama versi Septuaginta, dan Perjanjian Baru. Dalam studi naskah Alkitab terdapat istilah Codex uncial agung atau Great uncial codices karena dianggap sebagai naskah Alkitab tertua dan terlengkap. Yang termasuk dalam Great uncial codices adalah: Codex Alexandrinus, Codex Sinaiticus dan Codex Vaticanus. 
menjadi hal yang menarik untuk dibahas berkaitan dengan kehidupan keseharian penulis kitab ini. Informasi mengenai kehidupan rasul Yakobus lebih banyak diperoleh dari sejumlah catatan para sejarawan abad permulaan. Ada banyak pustaka yang menyampaikan hal tersebut, dan juga kesaksian para sejarawan, salah satunya adalah seorang bernama Hegesippus $^{39}$ yang dianggap memberikan masukan berharga dengan memberikan informasi mengenai kehidupan Yakobus. Tentunya sejarawan lainnya pun menyampaikan hal yang sama. Setidaknya hal tersebut dapat terlihat dari tulisan seorang tokoh lainnya yang bernama Eusebius $^{40}$ yang juga memberikan informasi penting tentang kehidupan Yakobus.

Tradisi gereja menyatakan bahwa Yakobus saudara Yesus baru menjadi orang percaya setelah setelah kebangkitan Yesus dari antara orang mati (1 Kor. 15:7). Kemudian ia menjadi pemimpin umat Kristen di Yerusalem, yaitu khususnya

\footnotetext{
${ }^{39}$ Hegesippus adalah sejarawan yang hidup setelah para rasul, dan ia banyak mencatat tentang hal-hal seputar gereja mula-mula. Salah satu karya terbesarnya adalah sebuah catatan kritis tentang ajaran sesat Gnostik dan Marcion.

${ }^{40}$ Eusebius dikenal karena karyanya: History of the Christian Church dianggap sebagai sumber penting dalam studi mengenai sejarah gereja. Tulisan lainnya, Chronicle, dan dua karya bersejarah lainnya, yang berjudul Martyrs of Palestine dan Life of Constantine. Informasi mengenai kehidupan Yakobus nampak jelas terurai dalam buku History of the Christian Church.
}

untuk kelompok Kristen yang berasal dari masyarakat Yahudi (Gal. 2:12).

Catatan Alkitab lainnya juga memberikan bukti bahwa rasul Paulus telah memandang Yakobus sebagai pribadi yang memiliki pengaruh dalam kehidupan umat Kristen. Bahkan bagi Paulus, Yakobus adalah sokoguru bagi jemaat Tuhan, sebagaimana yang sudah diungkapkan pada bagian sebelumnya (Gal. 2:9), dan salah satu pribadi yang berperan penting dalam sidang di Yerusalem (Kis. 15:13; Gal. 2:9).

\section{Unsur Pengajaran Penting dalam Kitab} Yakobus

Pada umumnya para ahli membagi Kitab Yakobus dalam 3 (tiga) bagian penting, yaitu: pertama, pengajaran penting tentang iman dan pencobaan (Yak. 1:1-12). Dalam bagian ini, Yakobus mengajarkan bagaimana orang percaya bersiap diri dalam menghadapi setiap pencobaan dengan iman yang sungguh di hadapan Tuhan (Yak. 1:12-18), dan hal itu ia lakukan karena melihat modal iman yang ada dalam diri orang percaya yang ia jumpai. Pengajaran ini sangatlah penting mengingat kaitan iman dan pencobaan merupakan suatu keterkaitan yang sedemikian kuat. Iman yang teguh, tak menggoyahkan seseorang ketika ia menghadapi pencobaan. Bahkan dikatakan 
bahwa pencobaan dapat menghasilkan hidup yang berkemenangan (Yak. 2-4,12; Yak 1:2-4,12).

Kedua, pengajaran penting tentang pencobaan (Yak. 1:13-4:12). Yakobus mengajarkan hal yang cukup penting dalam kehidupan umat percaya, yaitu berkaitan dengan aspek pencobaan yang dihadapi dalam kehidupan keseharian orang percaya. Kehidupan manusia yang dinamis dan seringkali berhadapan dengan hal-hal yang membuatnya goyah, perlu dicermati dengan baik. Yakobus bahkan menggiring umat Tuhan untuk tetap percaya sebagai bukti dari imannya kepada Tuhan, dan bahkan dengan tegas Yakobus menegur mereka yang dianggap kurang dalam menerapkan iman Kristen yang harusnya mereka buktikan dalam kehidupan kesehariannya (Yak. 2:26). Pengajaran Yakobus ini tidaklah bertentangan dengan keselamatan yang merupakan kasih karunia Tuhan (lihat Ef. 2:8-9), namun yang dimaksudkan adalah bagaimana seorang percaya menjalani kehidupannya secara bertanggung jawab. Hal tersebut seringkali dilupakan banyak orang sebagai bagian dari pencobaan yang harus dilalui oleh seorang percaya dan diharapkan ia akan sanggup menjalaninya dan berhasil.

Ketiga, pengajaran penting tentang tanggungjawab hidup orang percaya (Yak.
4:13-5:20). Salah satu poin penting yang diajarkan Yakobus dalam tulisannya itu adalah hal perencanaan (lihat Yak. 4:1317), yang tentunya dalam dunia manajemen terdapat analisa strategis perencanaan SWOT (Strength, Weekness, Opportunity, dan Threat). Dalam konteks tersebut, Yakobus membicarakan tentang para para pedagang, yang dalam pekerjaannya menuntut adanya sebuah perencanaan, sehingga pengajaran mengenai perencanaan menjadi hal yang penting dan itu merupakan tanggung jawab seorang percaya. Selain itu, bentuk tanggung jawab Kristen adalah jika seorang percaya menjalani kehidupan dengan benar. Sebagai contoh, Yakobus menasehati orang-orang kaya (Yak. 5:1-6), memberi nasihat tentang penderitaan (Yak. 6:7-11), dan tentang saudara seiman yang menderita (Yak. 5:12-20). Pengajaran Yakobus dalam bagian ini menekankan pentingnya seorang Kristen hidup secara bertanggung jawab.

Jadi Yakobus mengajarkan bahwa sekalipun orang Kristen sudah dimerdekakan dari dosa oleh iman kepada Kristus, namun hal itu tidak berarti bahwa ia bebas untuk hidup di dalam dosa. Dia harus menunjukkan imannya sebagai bukti dari kehidupan Kristen yang bertanggungjawab. 


\section{Daftar Pustaka}

Davids. H. Peter, I Howard Marshall and W Ward Gasque (ed.). New International Greek Testament Commentary: The Epistle of James. Grand Rapids, Mich.: Eerdmans, 1982. , James-New International Biblical Commentary (Massachusetts: Hendicson Publishers, 1983).

Drane, John. Memahami Perjanjian Baru. Jakarta: Gunung Mulia, 1998.

Gaebelin, E. Frank. The Practical Epistle Of James. New York:1954.

Groenen, C. Pengantar Ke dalam Perjanjian Baru. Yogyakarta: Kanisius, 1987.

Gromacki, G. Robert. New Testament Survey. Michigan: Grand Rapids, 1974.

Guthrie, Donald. Teologi Perjanjian Baru 3. Jakarta: BPK Gunung Mulia, 1992.

Guthrie, Donald, dkk. Tafsiran Alkitab Masa Kini 3 Matius-Wahyu. Jakarta: Yayasan Bina Kasih/OMF, 2003.

Ladd, George Eldon, Teologi Perjanjian Baru Jilid 2. Bandung: Yayasan Kalam Hidup, 2002.

Mc Bride. Alfred, Images of Mary. Jakarta: Obor, 2004.

Mc Cartney, G. Dan, Robert W Yarbrough and Robert H Stein, Exegetical Commentary on the New Testament: James. Grand Rapids: Baker Academic, 2009.

McKnight. Scot, The New International Commentary on the New Testament: The Letter of James. Grand Rapids, Michigan: William B. Erdmans, 2011.

Merril. C. Tenney, Survei Perjanjian Baru. Malang: Gandum Mas, 2009.

Moo, Douglas, The Latter of James. Grand Rapids: Wm. B. Edmans, 2000.

Susanto, Hasan, Surat Yakobus. Malang: Literatur SAAT, 2006.

Tamez, Elsa. Scandalous of James: Faith Without Works is Dead. New York: Crossroad, 1989.

van Niftrik, G.C. Dogmatika Masa Kini. Jakarta: BPK Gunung Mulia, 1995.

vaughan, Curtis. James. Michigan: Zondervan Publishing House, 1986. 